\title{
The Global Deluge: Floods, Diluvian Imagery, and Aquatic Language in Amitav Ghosh's The Hungry Tide and Gun Island
}

\author{
Dr Ursula Kluwick
}

English Department, University of Bern, Switzerland and English Department, AlbertLudwigs University of Freiburg, Germany

University of Bern, English Department, Laenggassstrasse 49, 3012 Bern, Switzerland; ursula.kluwick@ens.unibe.ch

The Global Deluge: Floods, Diluvian Imagery, and Aquatic Language in Amitav Ghosh's The Hungry Tide and Gun Island

This article reappraises the potential of realism with respect to the representation of climate change through an analysis of the figure of the flood in what I term Anthropocene water fictions. The article draws on Amitav Ghosh's nonfictional The Great Derangement (2016) together with his novels The Hungry Tide (2004) and Gun Island (2019), published before and after The Great Derangement, respectively. I argue that through their development of an aquatic language and diluvian imagery, Anthropocene water fictions challenge the limitations of realism that Ghosh identifies in The Great Derangement. Keywords: floods, water, blue humanities, ecocriticism, climate change, realism

In his Berlin Family lectures, published as The Great Derangement in 2016, Amitav Ghosh examines the reasons why 'serious' literary fiction, as he calls it, ${ }^{1}$ has found it so difficult to engage with the climate crisis, perfecting instead 'the modes of concealment that prevent $[\ldots]$ people from recognizing the realities of their plight' (11). Among his answers are the 'very high degree of improbability' of the 'weather events' associated with the climate crisis

\footnotetext{
${ }^{1}$ See Taylor $(2018,111,116$, and 125$)$ for a discussion of this point.
} 
(Ghosh 2016,26), a tradition of ignoring and silencing the nonhuman (30-33) and suppressing its agency (63-70), and limitations of scale.

As this list suggests, Ghosh's argument essentially concerns the traditional realist novel. Sidestepping his problematic refusal to take other genres such as science fiction seriously, ${ }^{2}$ in this article I reappraise the potential of realism with respect to the representation of climate change. I do so through an analysis of the figure of the flood in two of Ghosh's own novels: The Hungry Tide (2004) and Gun Island (2019), published before and after The Great Derangement, respectively. The Hungry Tide arguably marked Ghosh's acceptance into the ecocritical canon, as a writer concerned with environmental justice and with overlaps of ecological and postcolonial concerns in general. In Gun Island, its sequel-ofsorts, Ghosh returns to similar themes, with a novel that explicitly concentrates on the nexus between the climate and the refugee crises.

I read these texts as what I term Anthropocene water fictions. As I define them, these are texts that engage with environmental change caused by humans and that use water to convey this change, through its function as setting or plot element. While I focus on catastrophic events such as floods, I am also interested in diluvian imagery and what I call aquatic language: the use of expressions associated with water, particularly in non-aquatic contexts, that establishes a conceptual link between such contexts and water. In respect to climate change, it is my contention that Anthropocene water fictions challenge some of the limitations of the realist novel that Ghosh identifies. Before I begin with my analysis of Ghosh's contemporary water fictions, however, I briefly want to turn to a water novel written in a very different climate, George Eliot's Victorian realist novel The Mill on the Floss (1860), a text in whose critical history the status of the flood has played a crucial role. To

\footnotetext{
${ }^{2}$ See Heise's (2018) review of Ghosh for a response.
} 
approach Ghosh's modern Anthropocene water texts by way of this early flood novel, a text representative of classical realism and written by one of the key proponents of this genre, demonstrates the extent to which critical and writerly engagements with the flood as an environmental event have changed.

\section{Hindsight: Realism, George Eliot, and the Flood}

The Mill on the Floss famously ends with a double drowning. Its two protagonists, Maggie Tulliver and her brother Tom, capsize in the little boat that Maggie has rowed to the mill in which her estranged brother has been trapped by a flood. With Maggie's help, Tom manages to escape, but the two siblings' reconciliation in the midst of this crisis is swiftly followed by death: pieces of broken machinery bear down upon them on the rising waters, overturn their barge, and drown them.

Critics tend to be unhappy with this ending (Levine 2013, 72; Law 2010, 73). Simon Dentith $(2014,48)$ calls it 'fundamentally inauthentic (because arbitrary)', an appraisal that is shared by Barbara Hardy $(1970,50)$, who objects 'to the bad faith that contrasts so strongly with the authenticity of everything that comes before'. And George Levine $(2013,72)$, though appreciating that the 'wonderful ending' is 'brilliantly and powerfully done', claims that 'it feels, aesthetically, like a surrender'. In conjuring up the flood, he argues, 'the novel resorts to those devices of fable', choosing a contrived way out of an otherwise 'irresolvable crisis' (Levine 2013, 73).

As the references to the inauthenticity and fable-like quality of the ending of The Mill on the Floss suggest, such negative appraisals of Eliot's flood are connected to her status as a realist writer. Dentith, Hardy, Levine, and others ${ }^{3}$ object to the flood because they regard it as

\footnotetext{
${ }^{3}$ Law (2010, 73-74) gives an overview of critical readings of the ending of The Mill of the Floss.
} 
a deus-ex-machina without any plausible basis within the fictional world of Eliot's text. Unable to resolve Maggie's crisis convincingly within the confines of realist verisimilitude, Eliot 'redeems' (Levine 2013, 73) her heroine with the help of an age-old figurative device, the purifying flood. The flood is considered a literary trick and its nature predominantly symbolic. Within the context of Eliot's realism, it hence appears contrived.

This assessment, however, is in conflict with what we know about Eliot's own investment in the flood. On 12 January 1859 , she recorded in her journal that 'We went into town to-day and looked in the "Annual Register" for cases of inundation' (Cross 1885, 58). As Gordon S. Haight (1980, xiii) clarifies, this constitutes her 'earliest reference' to the novel. Together with her well-documented search in 1859 for a geographical location that would provide a credible setting for the flood, this demonstrates that the latter was part of her vision from the first. Haight's (1980) description of her collection of accounts of floods and of trips Eliot and George Henry Lewes undertook in order to study different rivers for their potential of flooding suggests that Eliot wanted her flood to be realistic. After studying 'rivers in Dorset and Nottinghamshire', she finally settled on the Trent in Lincolnshire, 'a tidal river with an eager or bore' (Haight 1980, 464) liable to flooding when high tides coincided with a freshet. The care with which she chose this location, even as she continued to draw on childhood memories of different places for the fictional landscapes through which Maggie moves indicates that for Eliot, the flood was a central, and certainly no 'arbitrary' fictional event.

Nevertheless, critical reactions to Eliot's flood were sceptical from the start, and Eliot partly concurred with this judgement. Henry James wondered whether the ending was 'a tardy expedient for the solution of Maggie's difficulties' (quoted from Haight 1980, xiii), and in a letter to her publisher John Blackwood, written on 9 July 1860, Eliot herself professed to 
'recognize the justice' of Edward Lytton's criticism 'that the tragedy is not adequately prepared':

This is a defect which I felt even while writing the third volume, and have felt ever since the MS. left me. The Epische Breite into which I was beguiled by love of my subject in the two first volumes, caused a want of proportionate fullness in the treatment of the third, which I shall always regret. (Cross 1885, 190)

Apparently, and notwithstanding the pains to which she had gone in order to find a credible setting, Eliot could not, finally, persuade herself that she had delivered a realistically convincing flood.

Eliot's dissatisfaction, together with the critical unease surrounding the diluvian ending of The Mill on the Floss, suggests that in the mid-nineteenth century, when The Mill on the Floss was published, floods in English literature were symbolically charged to an extent that all but erased their referential function. ${ }^{4}$ Read from within this tradition, Eliot's denouement jars with the realism of her novel. Our current climate, however, enables a different approach to the flood. As Jules Law (2010) points out in his recent discussion of The Mill on the Floss, previous readings of Eliot's flood have tended to be 'allegorical' even when they defended the ending of her novel. Law $(2010,73)$ himself, by contrast, strives to 'understand as specifically as possible the relationship of the novel's historical and material references $[\ldots]$ to the novel's plot'. As he demonstrates, Eliot's novel 'is driven by the flow of a river - in every literal way conceivable', and her plot 'insistently subordinates the lives of its characters to an unfolding drama concerning legal and technological attempts to control the flow of the river Floss and its tributaries' (Law 2010, 72). From this perspective, the mill

\footnotetext{
${ }^{4}$ For another example, consider the symbolism of Charles Dickens's inundated Lincolnshire in Bleak
} House (1952). 
and river are central to The Mill on the Floss, as are the consequences that changes to the agricultural use of watercourses and to water rights have for the social web portrayed.

This brief overview of the critical history of The Mill on the Floss reveals a profound shift in assessments of floods in literature. Law's analysis of Eliot's novel constitutes a reading fundamentally different from that typical of traditional approaches to this text, a reading that is attuned to the precise intersections between material contexts, environmental conditions, and plot. Interest in such connections is characteristic of reading practices fostered by awareness of the Anthropocene, whose rise has been accompanied by a renewed interest in the physical properties of environments and their interactions with humans. As both critics and writers have become more conscious of such links, the status of environmental events in literature has changed. With respect to the topic of this special issue, this means that the function of floods in literature is no longer predominantly symbolic. As Bracke $(2019,278-279)$ and Trexler $(2015,83)$ both demonstrate, the flood is now one of the most frequent literary tropes of climate change. With the strong focus on melting ice caps in climate change discourse, the flood has become a plausible literary device that is fully compatible with realism. At the same time, this re-appraisal of floods also makes it possible to re-read novels such as Eliot's, as Law does, from a stance that is more alert to materialist connections and renders visible the ways in which her flood is consistent with other descriptions of the interdependencies between humans and their environment in the novel.

\section{Aquatic Agency and the Visibility of the Nonhuman}

In The Great Derangement, Amitav Ghosh foregrounds the need for fictions that are able to 'communicate $[\ldots]$ the uncanniness and improbability, the magnitude and interconnectedness of the transformations that are now under way' $(2016,73)$. The modern novel, he contends, has not yet been able to meet this task, largely due to its failure to convey the agency of the 
nonhuman: 'Inasmuch as the nonhuman was written about at all, it was not within the mansion of serious fiction but rather in the outhouses to which science fiction and fantasy had been banished' (Ghosh 2016, 66). Such an automatic relegation of the nonhuman to the realm of the improbable is tantamount to its devaluation: the idea that the nonhuman environment has agency is characterised as fantastic.

But Ghosh is too hasty in his dismissal of the achievements of 'serious fiction'. As my overview of critical reactions to The Mill on the Floss suggests, what is at stake here is not the ability of the realist novel to represent the nonhuman, but a tradition of reading that disregards nonhuman agency unless it is foregrounded in the shape of fantastic monsters such as vampires. I am far from suggesting that there is no need for fiction to develop new means of meeting the challenges of representation inherent in climate change. What I am proposing, however, is that fiction already has many subtle ways of expressing nonhuman agency, and that the type of sensibility that is currently being fostered by the sudden and unprecedented prominence of climate change in the media might help raise their visibility. This article shows that water fictions play a key role in this process.

Many of the novels that address the climate crisis are set in aquatic landscapes or describe catastrophic aquatic events, such as floods, storms, and tsunamis. The fact that littoral landscapes are especially vulnerable to global warming partly explains this prominence of aquatic space. Beaches and coastlines tend to show the impact of rising sea levels early on and in a manner that renders environmental as well as social consequences of climate change tangible. ${ }^{5}$ However, there is more to the role of aquatic landscapes for climate change literature. As recent advances in the Blue Humanities have shown, waterscapes foreground processuality, enabling a new perspective on space as emergent (Steinberg and

\footnotetext{
${ }^{5}$ See, for instance, Alexa Weik von Mossner's $(2015,184-186)$ discussion of Briar March's There
} Once Was an Island, a 2010 documentary about the gradual submersion of the island of Takuu. 
Peters 2015,250$)$ that automatically also challenges conceptualisations of space as passive. Through their inherent processuality, waterscapes and aquatic events make visible nonhuman agency. I contend that floods are among the most forceful examples of environmental agency in a larger web of human-aquatic interconnections in Anthropocene water fictions and that novels emphasise this through the development of diluvian imagery and aquatic language.

In The Hungry Tide, the flood is literally among the first things the reader encounters, as the table of contents announces the two parts of the novel as 'The Ebb: Bhata' and 'The Flood: Jowar'. This indicates that in this novel, the flood functions on several levels: it is both a structural principle and part of the continuous cyclical process of the tides that shape the Sundarbans in which Ghosh sets his text. Periodic submergence and metamorphosis provide the rhythm to human and nonhuman existence alike in Ghosh's 'tide country'. As Jaising $(2015,74)$ argues, 'tidal patterns inspire the novel's contemplation of the relationship between human beings and their environments'. Thus, through its structural division, the novel confirms the fundamental interconnection between human characters and nature in its very form. ${ }^{6}$

The tides are an active force in this relationship. Ghosh's character Nirmal, the Marxist philosopher and schoolteacher whose journal provides one of the main narrative strands of the novel, sketches the principal metamorphic nature of the Sundarbans as follows: 'in the tide country, transformation is the rule of life: rivers stray from week to week, and islands are made and unmade in days' (Ghosh 2004, 224; italics in original). The tide country is shaped and continuously reshaped by the agency of water. Rivers choose new paths and in the process re-construct their surroundings. While this metamorphosis is part of the natural processuality of this liminal land-waterscape, however, it is not without its

\footnotetext{
${ }^{6}$ Jens Martin Gurr $(2010,70)$ shows that the form and plot of The Hungry Tide reflect each other in the 'underlying "deep structure" of ebb and flood'.
} 
uncanny aspects. As Nirmal concludes, 'nothing escapes the maw of the tides' (Ghosh 2004, 225 ; italics in original). Change is envisioned as a form of digestion in which the flood devours the land and everything else with which it comes into contact.

Rather than merely a sign of the natural provisionality and transformability of the tide country, then, the agency of the tides is also threatening. In The Hungry Tide, this is related to the idea that time in the Sundarbans passes more quickly than elsewhere: 'Could it be that the very rhythms of the earth were quickened here so that they unfolded at an accelerated pace?' asks Nirmal (Ghosh 2004, 224; italics in original). Viewed in the context of climate change, this indeed appears to be the case. Brandon Jones $(2018,645)$ claims that sea levels in the Sundarbans are 'rising faster than anywhere else on earth', and according to a study published in 2012, this means 'at a rate almost double the global average' since the late 1980s (Mahadevia and Vikas 2012, 8). The flood, in this sense, stands not only for periodic but also for a more permanent and destructive submergence. ${ }^{7}$

The consequences of this development are dire. The inhabited islands in the Sundarbans archipelago consist of reclaimed land, and human settlements rely on strong protective embankments, such as dams. However, it is clear that these cannot take much higher sea levels (Schwarzstein 2019). Ghosh sketches the fragility of the human presence in this land-water interface in his first description of the fictional island of Lusibari, one of his main Sundarbans settings:

At low tide, when the embankment was riding high on the water, Lusibari looked like some gigantic earthen ark, floating serenely above its surroundings. Only at high tide was it evident that the interior of the island lay well below the level of the water. At such times

\footnotetext{
${ }^{7}$ The novel arguably foreshadows this in its two-part structure, as it ends on 'The Flood' without the relief of another 'Ebb'.
} 
the unsinkable ship of a few hours before took on the appearance of a flimsy saucer that could tip over at any moment and go circling down into the depths. (Ghosh 2004, 37)

Instability is a fundamental characteristic of the Sundarbans archipelago, but while the action of the tides is an integral element of its ecosystem, rising sea levels and storm waves threaten to bring it to the point of collapse: without divine protection, left to the agency of the rising waters, Noah's Ark can easily be shipwrecked.

\section{Submergence: Accelerating Climate Change from The Hungry Tide to Gun Island}

Both The Hungry Tide and Gun Island address ecological destruction in the Sundarbans through cyclones and floods, but they favour different scales of representation: while the former novel focuses on local consequences, the latter ties local destruction to its global repercussions. The Hungry Tide depicts two different cyclones in considerable detail: the 1970 one is remembered by a character, while another cyclone hits the Sundarbans towards the end of the novel. Gun Island, by contrast, briefly mentions one cyclone, Aila of 2009, but manages to convey an even greater sense of devastation by connecting the storm with climate change migration and permanent social change. In what follows, I concentrate on the development of Ghosh's engagement with the flood in his increasingly explicit exploration of climate change. I identify a shift from depictions of cyclones as lived experience to storms and floods as signs of climatic and harbingers of social change. At the same time, I argue that floods become increasingly important as links between different events and settings, as is also apparent in the aquatic language of Gun Island.

In The Hungry Tide, cyclones are part of the natural history of the tide country, but their impact is consistently personalised. This is most obvious in a passage in which Nirmal records how he teaches a young boy, Fokir, about the Sundarbans through the history of its storms. Using signs of previous breaches in the bãdh, the embankment of Lusibari, as triggers 
for stories about human settlement, he translates a long historical timespan into a series of individual scenes. Talking about a storm that destroyed a kilometre of the embankment in the 1930s, for instance, he asks Fokir to imagine his 'ancestors':

After years of living on stilt-raised platforms, they had finally been able to descend to earth and make a few shacks and shanties on level ground. All this by virtue of the bãdh. And imagine that fateful night, when the storm struck, at exactly the time that a kotal gon was setting in; imagine how they [...] watched the waters, rising, rising, gnawing at the mud and the sand they had laid down to hold the river off. Imagine what went through their heads as they watched this devouring tide eating its way through the earthworks, stalking them wherever they were. (Ghosh 2004, 203; italics in original)

By individualising this scene and focussing on the emotions felt by the islanders whom he casts as Fokir's 'ancestors', Nirmal invites identification, thus rendering the action of the tide all the more upsetting. Aquatic agency is clearly cast as uncanny. The flood is a 'devouring' monster that eats away at the embankment, confronting the islanders with the elusiveness of their own marks. Nirmal is describing a cyclone, but rather than presenting the flood in terms of a violent, albeit temporally restricted, sudden onslaught, he includes the storm in a broader picture of steady erosion. The tide is 'stalking' the villagers, erasing the result of 'years of struggle' with its dogged 'gnawing' (Ghosh 2004, 203). It is precisely this persistence of the waters that points to their future triumph. As Nirmal's tale suggests, storms are peaks in a long process of flooding that will end in submergence: 'My friend, not only could it happen again - it will happen again. A storm will come, the waters will rise, and the bãdh will succumb, in part or in whole. It is only a matter of time' (Ghosh 2004, 205; italics in original). Refusing to reassure Fokir and assuming the role of a prophet of doom, Nirmal predicts the eventual disappearance of human settlements in the tide country.

The plot of the novel, however, does not confirm this vision. Though its climax is constituted by a cyclone, the focus on individual experience in the narration of the storm 
keeps the novel from adopting Nirmal's larger perspective. ${ }^{8}$ Like most of the novel, the storm chapters are narrated through variable focalisation, shifting between Kanai, Nirmal's nephew, who has come to the Sundarbans to read the notebook in which Nirmal recorded much of his involvement with refugees in the Sundarbans, and Piya, a cetologist conducting research in the Sundarbans with the help of Fokir, now an adult. These sections are closely intertwined, as focalisation moves frequently within the short chapters of the novel. In the storm chapters, this style of narration results in two highly personalised and near instantaneous accounts of the storm as simultaneous but individual experiences. Kanai and Piya are both out on the waters as the storm begins, but while Kanai is taken to safety, Piya and Fokir have to brave the storm.

The storm and flood are depicted in terms of a gradual ascendancy of environmental over human agency. As Piya and Fokir row across the increasingly choppy waterways, Piya initially has confidence in their own physical strength: 'If they managed to keep up the pace, she calculated that they would be back at Garjontola in a couple of hours' (Ghosh 2004, 369). At this point, the waves appear to her as 'extra pairs of hands to help with the rowing' (Ghosh 2004, 369). But the waters do not continue to be so forthcoming, and Piya soon feels her own agency slipping away:

[...] now Piya found herself rowing with her back to the wind. It was oddly disorientating to be hit by waves coming from her blind side; after they had lifted her up there would be a dizzying moment when the boat seemed to hang upon the crest of the watery ridge. Then suddenly she would find herself tobogganing backwards into the wave's trough, clutching at the gunwales to keep her balance. (Ghosh 2004, 370)

${ }^{8}$ In fact, it is as a result of the cyclone that Piya, an American of Indian descent, establishes a conservation project in the area, intended to benefit not only the nonhuman but also the human inhabitants of the Sundarbans (Ghosh 2004, 396-400). 
Though she is still rowing, Piya is now at the mercy of the waves. While the previous passage highlights human determination and vigour, playing down aquatic agency by describing the waves as helpmates, the water has gained the upper hand in the second quotation. Syntactically, Piya is now associated with the passive voice and the object case: she is 'hit by waves', and the waves 'lift [...] her up'. The recurrent construction of 'find' plus gerund, though active, also robs Piya's actions of any sense of deliberateness: 'she found herself rowing', 'she would find herself tobogganing'. Piya has clearly lost control over her own movements; instead, this passage highlights the fragility of the boat and its passengers as they are thrown about by the increasingly ferocious waters.

The full force of this confrontation is apparent when an enormous tidal wave breaks over Fokir and Piya. By this point, they have reached one of the islands and fastened themselves to a tree. As the tidal wave races towards them, it initially creates utter confusion. The sense of disorientation that is already expressed in the passage above reaches a new level. Piya is trying to figure out what she is seeing, but because this is represented through psychonarration and by an extradiegetic narrator, it is as if the novel itself were unable to find the right terms for what it wants to describe:

[...] Piya glimpsed something that looked like a wall, hurtling towards them, from downriver. It was as if a city block had suddenly begun to move: the river was like pavement, lying at its feet, while its crest reared high above, dwarfing the tallest trees. It was a tidal wave, sweeping in from the sea; everything in its path disappeared as it came thundering towards them. Piya's mind went blank as disbelief yielded to recognition. (Ghosh 2004, 383)

Initially, Piya's struggle to make sense of what is happening is conveyed through a series of similes that only succeed in likening the wave to what it is not. Paradoxically, however, when Piya is finally able to give a name to what she is seeing, rather than clarity this act of identification creates yet more confusion. The wave erases the familiar world, and this 
obliteration is reflected in Piya's 'mind'. It is precisely at the moment she arrives at 'recognition', a moment that normally signals consolidation of meaning and should thus also render possible conceptualisation and naming, that she is faced with a conceptual 'blank'.

In The Great Derangement (2016, 29 and 30), Ghosh links such moments of fundamental 'strangeness', when 'your mind is in a state unlike any you've known before' with the uncanny. In The Hungry Tide, Piya experiences precisely such an onslaught of the uncanny when the land-waterscape around her becomes so completely unfamiliar that it transcends her power of cognition, and, finally, her hold on language. This resonates with Astrid Bracke's $(2019,284)$ argument about the entropy of language in flood fictions, as expressive of 'a sense of alienation that captures the experience of understanding and living with climate crisis'. It is also related to a motif that conveys the direct threat to knowledge and civilisation posed by climate change: the loss of books and narratives (Bracke 2019, 283284). In The Hungry Tide, this surfaces in the loss of Nirmal's journal, which is swept away as Kanai is 'knocked sidewise into the water' by the storm: 'It stayed on the surface for a couple more minutes before sinking out of sight' (Ghosh 2004, 376). Since this journal constitutes one of the main narrative strands of The Hungry Tide, its disappearance allows the novel to imagine its own disintegration in its engagement with the flood. However, the very fact that the journal is preserved in the body of the material book The Hungry Tide also serves as an assertion of the continued relevance of the novel as a medium for narrating climate change.

As the passages from The Great Derangement quoted above show, since writing The Hungry Tide, Amitav Ghosh has begun to address the role of the novel for the representation of climate change more systematically. While he articulates his belief in its failures in The Great Derangement, Gun Island is a literary reply to his own theoretical deliberations. A loose sequel to The Hungry Tide in that it takes up the stories of some of the characters 
roughly ten years later while introducing a variety of new protagonists and settings, Gun Island approaches storms and floods in a manner markedly different from The Hungry Tide. In contrast to the extended narrative of the storm in the latter, Gun Island merely gives a brief summary of one character's recollections of the 1970 cyclone Bhola, a version of the same character's two-page account of the same storm in The Hungry Tide compressed into one short paragraph. This is related to differences in scope. While The Hungry Tide clearly acknowledges global connections through its engagement with environmental justice and the impact of international NGO conservation projects on the population of the Sundarbans, it is nevertheless an essentially local novel, ${ }^{9}$ almost exclusively set in the Gulf of Bengal. Gun Island, by contrast, is an emphatically global text. It begins in Kolkata and briefly moves to the Sundarbans, which one of its protagonists, Deen, visits in order to look at a small shrine that has been erected to commemorate the legend of the so-called Gun Merchant. For the rest of the novel, Deen will try to decode this obscure legend, in which a character is chased across the oceans by a vengeful goddess (reminiscent of Homer's Odyssey). As Deen deciphers more and more of the Gun Merchant's story, the legend emerges as an allegory of human hubris and global environmental collapse. Thus the tale of the Gun Merchant serves as a comment on climate change and human unwillingness to recognise the fundamental and inextricable connections between human actions and environmental change.

With its protagonist Deen, Gun Island moves from Kolkata to Brooklyn, to Los Angeles, to Venice, and finally to the Mediterranean Sea, where various opposed groups of activists gather to meet a refugee boat that has been denied permission to land in Italy. Over the course of these journeys, Deen encounters the climate crisis in various forms: in evidence of increased cyclone activity and strength in the Sundarbans; in wildfires raging around Los

\footnotetext{
${ }^{9}$ But see Alexa Weik (2006) on the complex relationship between the local and the cosmopolitan in this novel.
} 
Angeles; in the floods that threaten Venice; and in the refugees whose migrations are directly related to climate change.

In keeping with the global scope of Gun Island, here cyclones are not represented as personal experiences as they are in The Hungry Tide, but in terms of larger socio-economic constellations. In addition to being local catastrophes, they are also tied to the challenges facing global society, as is made explicit when characters discuss cyclones as direct causes of migration. On Deen's day-trip to the Sundarbans, for instance, a local nurse, Moyna, ${ }^{10}$ explains to him how the 2009 cyclone Aila differs from previous cyclones. Because warning systems have been active since the late 1990s, the death toll of Aila is lower than might be expected. However, it is its 'long-term consequences' that really distinguish it from previous storms:

Hundreds of miles of embankment had been swept away and the sea had invaded places where it had never entered before; vast tracts of once fertile land had been swamped by salt water, rendering them uncultivable for a generation, if not forever.

The evacuations too had produced effects that no one could have foretold. Having once been uprooted from their villages many evacuees had decided not to return [....] Communities had been destroyed and families dispersed; the young had drifted to cities, swelling already-swollen slums; among the elderly many had given up trying to eke out a living and had taken to begging on the streets. (Ghosh 2019, 52-53)

Cyclones like Aila cause social upheaval, putting more and more pressure on communities already on the edge. In the face of rising sea levels and land loss, human endeavours to preserve the agricultural value and hence the habitability of the region seem hopeless. Cyclones no longer signify a temporary rupture but a permanent structural change. The global dimension of this is made explicit:

\footnotetext{
${ }^{10}$ Moyna is Fokir's wife in The Hungry Tide, and his widow in Gun Island. Their son, Tutul/Tipu (as he now calls himself) is one of the protagonists of Gun Island.
} 
Making a life in the Sundarbans had become so hard that the exodus of the young was accelerating every year: boys and girls were borrowing and stealing to pay agents to find them work elsewhere. Some were slipping over the border into Bangladesh, to join labour gangs headed for the Gulf. And if that failed they would pay traffickers to smuggle them to Malaysia or Indonesia, on boats. (Ghosh 2019, 52-53)

As the further development of the novel shows, such migration is not confined to the East. When Deen is in Venice, he is startled to realise that he can hear Bangla everywhere, and as he follows these voices, he delves deep into a world of migrant labourers whose presence makes visible the exploitative global connections that the climate crisis reinforces. Leaving behind their sinking homeland, Bengali ecological refugees try to carve out a living in Venice.

Ironically, however, Venice is also a sinking city, another one of the places most vulnerable to climate change. There are concrete connections between Venice and the Sundarbans, not only in a (post)colonial and economic but also in an environmental sense. When Deen views Venice from a plane window, he realises that from 'that height it was possible to mistake the Venetian lagoon for the Sundarbans' (Ghosh 2019, 162). As the novel insists, this resemblance is indicative of the multi-layered connections that climate change renders visible between seemingly distant places. One example with which Gun Island engages more extensively is animal migrations caused by global warming. For instance, Deen finds a spider in a Venice flat that turns out to be a species native to the southeastern states of the USA (Ghosh 2019, 223). Other examples are the lethal yellow-bellied sea snakes that have begun to appear on the coasts of California (Ghosh 2019, 145-148), and the shipworm, 'invading Venice, with the warming of the lagoon's water' and 'literally eating [its] foundations' (Ghosh 2019, 251). Not only do rising temperatures create new species connections between disparate geographical locations, the fact that marine animals are gnawing away at the structures that make human habitation possible establishes a direct link 
between Venice and the Sundarbans, in which the burrowing of crabs erodes the bãdhs, as Nirmal points out in The Hungry Tide (205-6). As the last section of this article shows, such connections are reflected in Ghosh's use of diluvian imagery.

\section{The Scope of Climate Change: Figuring Global Connections through Diluvian Imagery}

When his Italian friend Cinta shows Deen the shipworms they accidentally break off a piece of railing and out comes a veritable flood of worms: 'We watched in horror as a mass of squirming shipworms came pouring out' (Ghosh 2019, 251). This is aquatic language: something that bears no relation to water (shipworm falling out of a piece of broken wood) is related through words normally associated with water or other liquids. In this specific instance, Ghosh's aquatic language ties species invasion to the figurative language of climate change through one of its predominant tropes: the flood. The novel further cements this link by combining this figurative flood with a genuine one. In the precise moment that the pier becomes uncannily alive with 'swarming' worms (Ghosh 2019, 252) the waters begin to rise. As Venice is hit by acqua alta, Cinta and Deen are cut off on the broken pier and threatened by environmental agency from all sides.

In his engagement with the scale of climate change, Ghosh expands the scope of his novel to embrace an extraordinary, and sometimes preposterous, mass of settings, topics, events, and characters. The proportions are Dickensian: in addition to the locations and events already mentioned, Ghosh touches on homophobia, xenophobia, the mafia and mob killings, dolphin beachings, trafficking, and prostitution; his cast of characters includes an antiquarian bookseller (Deen), a cetologist (Piya), an eminent historian (Cinta), a nurse (Moya), gay couples, human rights activists, journalists, refugees, and immigrant labourers. They are brought together to suggest that nothing lies outside the reach of climate change and that everything contributes to and is implicated in the present state of the world. 
Whereas Victorian realist novels fully embrace the intricate connections they construct and thus remain convincing within their generic parameters, however, Ghosh builds scepticism into the very structure of his novel. His protagonist Deen is a reluctant believer in the connections he himself helps reveal. Even as he tries to reconstruct the mythical Gun Merchant's global odyssey, he doubts every single piece of the puzzle that he finds. Significantly, this fear of irrationality is echoed by Piya, the scientist, and it is only through the influence of Cinta, the humanist, that Deen can finally bring himself to believe in the myriad links his search has uncovered and accept the agency of the nonhuman which is at the core of the Gun Merchant's tale. As a result of this persistent questioning, the novel is unable to fully endorse the reality of the connections it sketches. Instead, these can only be embraced in the form of the supernatural. In The Great Derangement, Ghosh $(2016,27)$ questions the effectiveness of magical realism as a mode of representing climate change precisely because climate change must be outside the reaches of doubt. It is unclear whether his reliance on the supernatural in Gun Island indicates the extent of his disillusionment with realism or a new confidence in representational departures from realism. In fact, it seems that the novel moves its alliances as it nears its conclusion. While for the most part, it argues that seemingly preposterous events, such as the death of a dog as the result of an attack by a tropical snake in California, are entirely plausible in the reality created by climate change, the text eventually becomes increasingly frenetic in its accumulation of bizarre occurrences. Significantly, however, and contrary to what Ghosh himself argues in The Great Derangement, its own loss of faith in realism does not concern the ability of realism to represent climate change but rather the potential of humanity to deal with the social consequences of global warming. It is when it addresses the fate of climate change refugees rather than the issue of climate change as such that the novel resorts to the unambiguous supernatural. 
But even in the climax of the novel, in which the text most fully embraces the supernatural, what holds the novel together is its diluvian imagery. As human rights activists and anti-refugee protesters are about to clash in the middle of the Mediterranean Sea, one group attempting to welcome the refugees, and the other to drive them away, nature herself comes to the rescue. The closer the human rights activists whom Deen has joined get to the refugees, the greater the variety of marine species they spot: 'We've sighted more than half the cetacean species of the Mediterranean, in one day', Piya exclaims (Ghosh 2019, 293). Eventually, these are joined by other species. As whales and dolphins 'whirl [...] around' the refugees' boat in the water, and millions of birds circle it from above, the sea itself begins to glow: “"Bioluminescence!” cried Piya. "I don’t believe it!”' (Ghosh 2019, 307). The novel presents this as a spiritual event: 'a halo of birds' and 'a chakra of dolphins and whales' orbit around an Ethiopian woman on the boat, who, as the novel suggests in its representation of this scene as a 'miracle' (Ghosh 2019, 309), is an incarnation of Manasa Devi, the snake goddess who also represents Mother Earth (307).

This scene is a clear deviation from realism. Ghosh admittedly prepares the reader for the appearance of the Ethiopian: Tipu earlier dreams of her and calls her 'a forishta, an angel' who draws him to Egypt (Ghosh 2019, 263; italics in original). And Manasa Devi, of course, is one of the protagonists of the legend of the Gun Merchant. Nevertheless, the generic switch here is surprising. Up to this point readers have been encouraged to read the various occurrences which the autodiegetic narrator Deen finds improbable as real consequences of climate change and to interpret Deen's doubt as his own inability to accept environmental agency. With the personification of environmental forces in the figure of the Ethiopian/Mother Earth, they are now suddenly asked for an entirely different suspension of disbelief. This is interesting since Gun Island arguably demonstrates that Ghosh has found a way to harness realism for the representation of climate change despite his own professed 
scepticism about the potential of this genre. Like Eliot in The Mill of the Floss, it is when Ghosh is faced with the task of imagining the social integration of characters who have lost their place (literally in the case of his climate change refugees) that he loses faith in realism. What makes this so surprising is that it directly contradicts the longstanding association between realism and the portrayal of social relations.

If this scene is irritating as far as its generic switch is concerned, it is nevertheless integrated into the larger aesthetic fabric of the novel through its aquatic language. It is in tune with the imagery of the novel that in the eyes of the characters this climatic event is also a flood. One character describes the multi-species gathering as 'the creatures of the sky and the sea rising up' (Ghosh 2019, 306), while Cinta talks of the 'joy [...] pouring over the horizon' (306), resorting to an image that is normally reserved for a tsunami. The birds are described through 'the Italian word for a flock of birds in flight': 'Uno stormo' - 'a storm of living beings' (Ghosh 2019, 307), and in contrast to the other storms and floods in Ghosh's two novels, this waterless storm is a benign sign of cross-species connection: 'as if some limb of the earth had risen into the heavens and were reaching out to touch us' (Ghosh 2019, 306).

In using the flood as a connector, the novel continues a technique begun much earlier: the various natural catastrophes which it presents as related to climate change are linked through diluvian imagery. The smoke billowing from the Californian wildfires, for instance, is compared to a 'distant tsunami of smoke' (Ghosh 2019, 144), 'an immense wave, complete with a frothing white top' that 'looked as though a gigantic tsunami were advancing upon the distant outskirts of the city' (134). As such imagery emphasises, what appear to be separate catastrophes are really different expressions of increasingly versatile and extreme meteorological patterns. Under the sign of climate change, the links between distant places the Sundarbans, Venice, and California - are moving into focus. In Gun Island, therefore, the trope of the flood is both the means through which Ghosh conveys the global material 
connectedness that climate change exposes and the leitmotif that prevents the disintegration of his text into disparate parts.

\section{Conclusion: Envisioning 'the ocean'd earth'}

As I have suggested, by imagining the multi-species gathering at the end of the novel through diluvian imagery, Ghosh also explores the symbolic potential of the flood as purification, a meaning integral to its long literary history. ${ }^{11}$ As Deen revels in the hope and harmony around him, he resorts to 'a phrase that recurs often in the Merchant legends of Bengal: sasagara basumati - "the ocean'd earth"” (Ghosh 2019, 295). From visions of destructive floods as signs of the dangerous global interdependencies characteristic of anthropogenic climate change, Ghosh's fiction thus takes his readers to an 'outpouring' of hope, a 'surging' of 'goodness, love, charity and generosity' (Ghosh 2019, 295), a world in which water is not only an agent of devastation but also a medium of cross-species support. As Cinta, functioning as her author's mouthpiece, claims, 'It is only through stories that the universe can speak to us, and if we don't learn to listen you may be sure that we will be punished for it' (Ghosh 2019, 141).

As the ending of The Mill on the Floss makes clear, the story Eliot tells is a tale of individual loss and redemption whose impact does not reach beyond the personal level. ${ }^{12}$ In her own short 'Conclusion', Eliot writes that 'Nature repairs her ravages, - repairs them with her sunshine and with human labour' (Eliot 2003, 543). Even though she immediately qualifies the idea that everything can be repaired, The Mill on the Floss nevertheless ends on

\footnotetext{
${ }^{11}$ And in stressing this symbolic meaning in the supernatural climax of his novel, Ghosh of course invites criticism similar to the one that has been directed at Eliot's flood.

${ }^{12}$ As Anne Sadrin concurs, 'the catastrophe is never felt, or meant to be felt, as universal' (2000,
} 102). 
a note of resilience: life in Eliot's fictional community goes on, and it is only a very few individual lives that have been more permanently affected by the flood.

As Ghosh's fiction demonstrates, under the sign of climate change, floods can no longer be seen as self-contained events. Both their causes and their repercussions are essentially global. Ghosh uses the trope of the flood to speak of human guilt and environmental destruction, of global connectedness, and of hope. Given the significantly heightened global awareness of climate change, the flood can nowadays function as a potent realist device to support the first two of these meanings. When it comes to the expression of hope, however, Ghosh's faith in realism fails. As Rob Nixon $(2011,10)$ argues, representational intervention 'entails devising iconic symbols that embody amorphous calamities as well as narrative forms that infuse these symbols with dramatic urgency'. Like many other writers of climate fiction, Ghosh finds a powerful narrative form in the flood: it provides the main structure for The Hungry Tide and it creates the links between disparate locations and events that ensure a clear narrative trajectory for Gun Island. In addition, aquatic language provides him with an effective tool that allows him to express nonhuman agency within the established repertoire of realism. Contrary to his own argument in The Great Derangement, therefore, Ghosh shows that the realist novel is capable of representing climate change. Eliot's efforts to write a realist flood were thwarted by readings, including her own, that were unable to conceptualise the flood as anything but symbolic. For Ghosh, both the realist and the symbolic meaning of the flood are accessible and both are equally powerful. However, his final fusion of the symbolic with the supernatural in the vision of 'the ocean'd earth' indicates that for him, any productive human response to climate change still lies outside the representational boundaries of realism and in the realm of the miraculous. 


\section{Works Cited}

Bracke, Astrid. 2019. "Flooded Futures: The Representation of the Anthropocene in TwentyFirst-Century British Flood Fictions." Critique: Studies in Contemporary Fiction 60 (3): 278-288, DOI: 10.1080/00111619.2019.1570911.

Cross, J. W. ed. 1885. Vol. 2 of George Eliot's Life as Related in Her Letters and Journals.

New York: Harper and Brothers.

Dentith, Simon. 2014. Nineteenth-Century British Literature Then and Now: Reading with Hindsight. Farnham: Ashgate.

Eliot, George. (1860) 2003. The Mill on the Floss. Edited and with an Introduction by A.S. Byatt. London: Penguin.

Gosh, Amitav. 2004. The Hungry Tide. London: HarperCollins.

---. 2016. The Great Derangement: Climate Change and the Unthinkable. Chicago: University of Chicago Press.

---. 2019. Gun Island. London: John Murray.

Gurr, Jens Martin. 2010. “Emploting an Ecosystem: Amitav Ghosh's The Hungry Tide and the Question of Form in Ecocriticism.” In Local Natures, Global Responsibilities, edited by Laurenz Volkmann, Nancy Grimm, Ines Detmers, and Katrin Thomson, 6980. Amsterdam: Rodopi.

Haight, Gordon S. 1980. "Introduction.” In The Mill on the Floss by George Eliot, xiiixxxvii. Oxford: Clarendon.

---. 1980. "Appendix A: Geography of The Mill on the Floss." In The Mill on the Floss by George Eliot, 463-467. Oxford: Clarendon.

Hardy, Barbara. 1970. “The Mill on the Floss.” In Critical Essays on George Eliot, edited by Barbara Hardy, 42-58. London: Routledge and Kegan Paul.

Heise, Ursula K. 2018. “Climate Stories: Review of Amitav Ghosh's The Great Derangement." boundary 2, February 2018. Accessed 14 January 2020. https://www.boundary2.org/2018/02/ursula-k-heise-climate-stories-review-of-amitavghoshs-the-great-derangement/

Jaising, Shakti. 2015. "Fixity Amid Flux: Aesthetics and Environmentalism in Amitav Ghosh's The Hungry Tide." Ariel: A Review of International English Literature 46 (4): 63-88. DOI: 10.1353/ARI.2015.0028. 
Jones, Brandon. 2018. “A Postcolonial Utopia for the Anthropocene: Amitav Ghosh's The Hungry Tide and Climate-Induced Migration.” Modern Fiction Studies 64 (4): 639658. DOI: 10.1353/MFS.2018.0047.

Kluwick, Ursula. 2019. “Aquatic Matter: Water in Victorian Fiction.” Open Cultural Studies 3: 245-255. DOI: 10.1515/CULTURE.2019.0022.

Law, Jules. 2010. The Social Life of Fluids: Blood, Milk and Water in the Victorian Novel. Ithaca: Cornell University Press.

Levine, George. 2013. “The Mill on the Floss and the 'Spirit' of Capitalism.” In Form and Feeling in Modern Literature: Essays in Honour of Barbara Hardy, edited by William Baker and Isobel Armstrong, 63-74. London: Legenda.

Mahadevia, Kanksha, and Mayank Vikas. 2012. "Climate Change - Impact on the Sundarbans: A Case Study." Journal of Environmental Science 2 (1): 7-15. Available at SSRN: abstract $=3389022$.

Nead, Lynda. 1990. Myths of Sexuality: Representations of Women in Victorian Britain. Oxford: Blackwell.

Nixon, Rob. 2011. Slow Violence and the Environmentalism of the Poor. Cambridge: Harvard University Press.

Sadrin, Anny. 2000. “Time, Tense, Weather in Three 'Flood Novels', Bleak House, The Mill on the Floss, To the Lighthouse.” The Yearbook of English Studies 30: 96-105.

Schwartzstein, Peter. 2019. "This vanishing forest protects the coasts—and lives—of two countries.” National Geographic, July 2019. Accessed 20 January 2020. https://www.nationalgeographic.com/magazine/2019/07/sundarbans-mangrove-forestin-bangladesh-india-threatened-by-rising-waters-illegal-logging/

Steinberg, Philip, and Kimberley Peters. 2015. "Wet Ontologies, Fluid Spaces: Giving Depth to Volume Through Oceanic Thinking." Environment and Planning D: Society and Space 33 (2): 247-264. DOI: 10.1068/D14148P.

Taylor, Jesse Oak. 2018. “The Novel after Nature, Nature after the Novel: Richard Jefferies's Anthropocene Romance." Studies in the Novel 50 (1): 108-133. DOI: 10.1353/SDN.2018.0006.

Trexler, Adam. 2015. Anthropocene Fictions: The Novel in a Time of Climate Change. Charlottesville: University of Virginia Press.

Weik von Mossner, Alexa. 2015. "Slow Violence on the Beach: Documenting Disappearance in There Once Was an Island." In The Beach in Anglophone Literatures and Cultures: 
Reading Littoral Space, edited by Ursula Kluwick and Virginia Richter, 175-191. Burlington: Ashgate.

---. 2006. "The Home, the Tide, and the World: Eco-cosmopolitan Encounters in Amitav Ghosh's The Hungry Tide.” Journal of Commonwealth and Postcolonial Studies 13 (2): 120-141. 